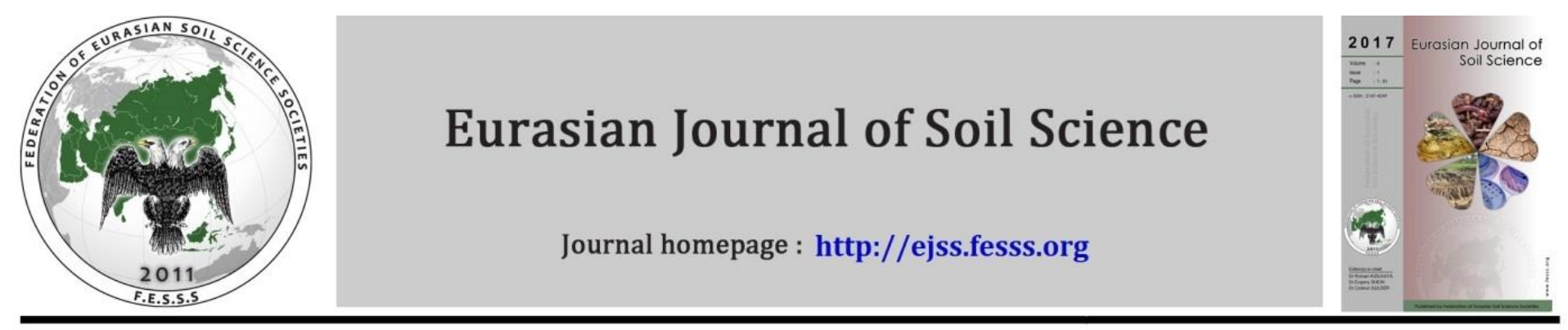

\title{
Synergistic use of nitrogen and zinc to bio-fortify zinc in wheat grains
}

\section{Muhammad Ahmed Akram *, Nizamuddin Depar, Muhammad Yousuf Memon}

Soil \& Environmental Sciences Division, Nuclear Institute of Agriculture (NIA), Tando Jam, Sindh, Pakistan

\section{Article Info}

Received : 24.01.2017

Accepted : 07.04.2017

\begin{abstract}
Our daily diet is largely contributed by cereals, which have low genetic abilities to amass higher concentrations of micronutrients in their grains. Hence, wide spread deficiencies iron, zinc and other essential nutrients have prevailed. Present study focuses the biofortification of $\mathrm{Zn}$ in wheat grains, taking advantage of nutrient-nutrient synergy between Zn and N. Three wheat genotypes (NIA-Amber, BWQ-4 and SD-998) were tested in a field experiment following randomized complete block factorial design with three replicates. Urea fertilizer was applied at the rates of 120 (recommended), 150 and $180 \mathrm{~kg} \mathrm{~N} \mathrm{ha}^{-1}$ in combination with three levels of $\mathrm{Zn}\left(0,5 \& 10 \mathrm{~kg} \mathrm{ha}^{-1}\right)$. Outcomes of the experiment revealed that NIA-Amber had the highest grain yield of 6.03 tons/ha against $150 \mathrm{~kg} \mathrm{~N}^{-1}$ and $10 \mathrm{~kg} \mathrm{Zn} \mathrm{ha-1}$. Maximum Zn contents of $447.86,429.56$ and $395.56 \mathrm{~g} \mathrm{ha}^{-1}$ were observed in BWQ-4, SD-998 and NIA-Amber at $180 \mathrm{~kg} \mathrm{~N}^{-1}$ in combination with $10 \mathrm{~kg} \mathrm{Zn}$ $\mathrm{ha}^{-1}$. Maximum enhancement in protein contents was observed in BWQ-4 (743 $\left.\mathrm{kg} \mathrm{ha}^{-1}\right)$ at $180 \mathrm{~kg} \mathrm{~N}$ ha-1and combined with $5 \mathrm{~kg} \mathrm{Zn} \mathrm{ha}^{-1}$. For NIA-Amber, $180 \mathrm{~kg} \mathrm{~N}^{\mathrm{N}} \mathrm{ha}^{-1}$ in

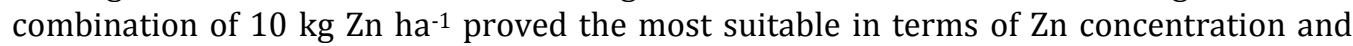
other quality attributes. Nitrogen @ 180 kg N ha-1 with $5 \mathrm{~kg} \mathrm{Zn} \mathrm{ha}^{-1}$ depicted appreciable zinc and protein contents in grains of BWQ-4 and SD-998.
\end{abstract}

Keywords: Bio-fortification, human nutrition, nutrient management.

(C) 2017 Federation of Eurasian Soil Science Societies. All rights reserved

\section{Introduction}

Bio-fortification is the production of crops with increased concentration of essentials minerals and protein to be provided to consumers through agricultural research and food trades (Allen, 2000). Such crops can serve as sustainable solution to the prevailing malnutrition among half of the world population (Riezzo et al., 2005).

Industrial fortification by supplementation and food processing; contrasts with bio-fortification (Vincent and Menefee, 2007; Mayer et al., 2008). Bio-fortification depends upon plant physiological efficiency of crops to accumulate higher concentration of desired mineral/nutrient (UNO, 2004; FAO, 2013). Breeding fortified crops, by using genetic variations and genetic modification can be a fruitful approach (Welch and Graham, 2004; Vijayaraghavan, 2002; Stein, 2006; Stein et al., 2007). Yet, fortification through nutritional management is of greater adaptability at farm level and less laborious (Bouis and Welch, 2010).

Cereals fulfill almost $61 \%$ of the total daily protein needs in human diet. Nitrogen has prime role in protein synthesis and crop yield especially in the country, where cereals are growing in almost $100 \% \mathrm{~N}$ deficient soils (Warraich et al., 2002). Crops respond to applied $\mathrm{N}$ due to its vital role in metabolism and growth (Abedi et al., 2010; Marino et al., 2011). Particularly, nitrogen in plants has role in proteins assimilation, protoplasm formation, nutrient regulation (Rodrigues et al., 2000), enzymatic functions and cell division (Oscarson, 2000; Warraich et al., 2002).

${ }^{*}$ Corresponding author.

Soil \& Environmental Sciences Division, Nuclear Institute of Agriculture (NIA), Tando Jam, 70060, Sindh, Pakistan 
Zinc is an important plant nutrient needed in small concentration. Its acute deficiency can lead up to $40 \%$ reduction in crop yield (Salvagotti and Miralles, 2007; Kutman et al., 2010; Kutman et al., 2011). Chlorophyll and auxin synthesis necessitate adequate Zn contents in plant tissues (Nadim et al., 2012; Jiang et al., 2013). Zinc also performs as cofactor to various enzymes hence, controls their activities. Wheat in comparison with other field crops has relatively better tolerance to Zn deficiency (Chauhan et al., 2014). However, its continuous cultivation in $\mathrm{Zn}$ deficient soils has resulted in wide spread $\mathrm{Zn}$ deficiency in grains; hampering crop production and causing low Zn supply to human (Chauhan et al., 2014).

Nitrogen and Zinc supplementations in wheat have prominent role in sustaining wheat production. The synergy between both can be used to augment Zn concentration in the edible portion and improving quality (Kutman et al., 2010; Shi et al., 2010; Cakmak, 2010; Cakmak et al., 2010a,b). Zinc uptake from soil to roots, mobilization in plant body and accumulation to sink is supported by nitrogenous proteins. (Wang et al., 2011). $\mathrm{N}$ is involved in the production of natural chelating agents (Kutman et al., 2010) like nicotianamine (NA) (Takahashi et al., 2003) and deoxymugeinic acid (DMA), involved in translocation of metals from flag leaves to grain (Barunawati et al., 2013). Therefore, the present study was executed to assess to N-Zn interaction to improve plant growth, nutrient contents, quality and Zn concentration in wheat grains.

\section{Material and Methods}

An field experiment was conducted at Nuclear Institute of Agriculture (NIA), Tando Jam, Sindh-Pakistan from $25^{\text {th }}$ November, 2015 to $18^{\text {th }}$ April, 2016. The experimental site was $29 \mathrm{~m}$ above sea level at latitude of $20^{\circ} 24^{\prime} 49.4^{\prime \prime}$ north and longitude of $68^{\circ} 31^{\prime} 03.7^{\prime \prime}$ east. The climate of the area is arid with an average high and low temperatures of $41^{\circ} \mathrm{C}$ and $11^{\circ} \mathrm{C}$, respectively and annual precipitation less than 10.8mm (NAMC, 2016). Eighty one experimental units each of $4 \mathrm{~m} \times 4 \mathrm{~m}$ were allotted to three wheat genotypes (NIA-Amber, BWQ-4 and SD-998). Nine treatment combinations of three $\mathrm{N}$ levels (120, 150 and $\left.180 \mathrm{~kg} \mathrm{ha}^{-1}\right)$ and three levels of $\mathrm{Zn}$ $\left(0,5\right.$ and $\left.10 \mathrm{~kg} \mathrm{ha}^{-1}\right)$ were applied to each genotype with three replications. Phosphorus in the form of diammonium phosphate $\left(90 \mathrm{~kg} \mathrm{P}_{2} \mathrm{O}_{5} \mathrm{ha}^{-1}\right)$ and potassium in the form of sulfate of potash $\left(60 \mathrm{~kg} \mathrm{~K}_{2} \mathrm{O} \mathrm{ha}{ }^{-1}\right)$ were applied at the time of sowing. Urea as nitrogen source was applied in three equal splits viz., at the time of sowing, tillering and panicle initiation. Zinc sulfate was applied along with second split of nitrogen to maintain three levels of zinc in the respective treatments. Experiment was irrigated with canal water at critical growth stages. Manual and chemical eradication of weeds and other cultural practices were performed as and when required. At harvest, yield attributes were recorded. From each replication, grain and straw samples were randomly collected and dried in oven at $70{ }^{\circ} \mathrm{C}$ for three days. A uniform portion of dried plant samples (straw and grain) was digested in di-acid $\left(\mathrm{HNO}_{3}\right.$ and $\left.\mathrm{HClO}_{4}\right)$ mixture for the determination of phosphorus and Zn (Chapman and Pratt, 1961). Vanadomolybdate yellow color method was used for the determination of phosphorus (Ryan, 2000). Zn concentrations were determined as described by Rashid (1986) by using atomic absorpotion spectrophotomerty (Analytical jena AAS-NOVA400, Germany) in digested samples. Grain N was determined through Kjeldal method (Jones, 1991). Subsequently, protein contents were calculated by multiplying grain $\mathrm{N}$ with 6.25 (FAO, 2003). Statistical analysis were performed using Statistix 8.1 at 5\% probability level.

\section{Results}

Data recorded for the yield attributes (Table 2) of wheat depicted that higher doses of $\mathrm{N}$ appreciably increased grain yield in comparison to $120 \mathrm{~kg} / \mathrm{ha} \mathrm{N}$ (recommended dose). The grain yield increased by 29, $24 \& 32 \%$ over $120 \mathrm{~kg} \mathrm{~N}^{-1}$ when NIA-Amber, BWQ-4 and SD-998 were supplemented with $150 \mathrm{~kg} \mathrm{~N} \mathrm{ha}^{-1}$. On application of $180 \mathrm{~kg} \mathrm{~N}^{-1}$ recorded grain yields of NIA-Amber, BWQ-4 and SD-998 were 2, $1 \& 4.6 \%$ higher than that of recommended N level. Similarly, straw yields were also enhanced up to $16,1 \& 24 \%$ by increasing $\mathrm{N}$ dose for $120 \mathrm{~kg} \mathrm{ha}^{-1}$ to $150 \mathrm{~kg} \mathrm{ha}^{-1}$. Highest straw yields were recorded when $\mathrm{N}$ was supplemented @180 kg ha-1. Crop yield was affected positively by the application of $\mathrm{Zn}$ in combination with all levels of $\mathrm{N}$ input. Maximum grain yield of $6.03 \mathrm{t} / \mathrm{ha}$ was recorded in NIA-Amber with $5 \mathrm{~kg} \mathrm{Zn}+150 \mathrm{~kg} \mathrm{~N}$ $\mathrm{ha}^{-1}$ which was statistically similar to grain yield (6.01 t/ha) of genotype SD-998 achieved by the application of $10 \mathrm{~kg} \mathrm{Zn}+180 \mathrm{~kg} \mathrm{~N} \mathrm{ha}^{-1}$. However, grain yield remained almost stagnant with the increase of input rates from higher to highest. Straw yield was also improved by the interactive use of $\mathrm{N}$ and $\mathrm{Zn} 10.45 \mathrm{t} / \mathrm{ha}$ was recorded as highest among all genotypes shown by SD-998 at $10 \mathrm{~kg} \mathrm{Zn}+180 \mathrm{~kg} \mathrm{~N} \mathrm{ha}^{-1}$.

Increasing the $\mathrm{N}$ dose in wheat from 120 to $180 \mathrm{~kg} \mathrm{~N}^{-1}$ escalated $\mathrm{N}$ contents (Table 3 ) in grain from 53.64 to $88.64 \mathrm{~kg} \mathrm{~N} \mathrm{ha}^{-1}$ in NIA-Amber, from 78.45 to $104.77 \mathrm{~kg} \mathrm{~N} \mathrm{ha}^{-1}$ in BWQ-4 and from 64.68 to $102.32 \mathrm{~kg} \mathrm{~N} \mathrm{ha}^{-1}$ in SD-998. Upon application of Zn doses (5 and $10 \mathrm{~kg} \mathrm{ha}^{-1}$ ) further increase in $\mathrm{N}$ contents was recorded. 
Grain contents of $135.64 \mathrm{~kg} \mathrm{~N}^{-1}$ by BWQ-4 in response to interactive use of $10 \mathrm{~kg} \mathrm{Zn+180} \mathrm{\textrm {kg } \mathrm { N } ^ { - 1 } \text { was }}$ highest among all the genotypes in comparison to all $\mathrm{Zn}+\mathrm{N}$ combinations. Increase in phosphorus uptake (Table 3) was recorded with increasing the $\mathrm{N}$ in all the genotypes however with the application of $\mathrm{Zn}, \mathrm{P}$ uptake tended to decrease slightly. In NIA-Amber, BWQ-4 and SD-998 P uptake decreased from 13.78 to $11.58 \mathrm{~kg} \mathrm{P} \mathrm{ha}^{-1}$, from 13.53 to $9.88 \mathrm{~kg} \mathrm{P} \mathrm{ha}^{-1}$ and from 15.99 to $15.10 \mathrm{~kg} \mathrm{P} \mathrm{ha}^{-1}$ with increasing Zn from 5 to 10 $\mathrm{kg} \mathrm{ha}^{-1}$ in combination with $120 \mathrm{~kg} \mathrm{~N} \mathrm{ha}^{-1}$. While average $\mathrm{P}$ uptake of the genotype was reduced from 22.44 to $18.74 \mathrm{~kg} \mathrm{P} \mathrm{ha}^{-1}$ when $\mathrm{Zn}$ was applied with $150 \mathrm{~kg} \mathrm{~N} \mathrm{ha}^{-1}$. Similar, results were recorded in case of $180 \mathrm{~kg} \mathrm{~N}$ $\mathrm{ha}^{-1}$ applied to wheat along with 5 and $10 \mathrm{~kg} \mathrm{Zn} \mathrm{ha}^{-1}$ and mean reduction of $1.8 \mathrm{~kg} \mathrm{P}^{-1}$ was observed. Zn contents (Table 4) in edible portion of wheat were enhanced by the interactive use of $\mathrm{N}$ and Zn. Significant increments from $55.78 \mathrm{~g} \mathrm{Zn} \mathrm{ha}^{-1}$ to $171.79 \mathrm{~g} \mathrm{Zn} \mathrm{ha}^{-1}, 135.59$ to $320.65 \mathrm{~g} \mathrm{Zn} \mathrm{ha}^{-1}$ and 173.33 to $424.33 \mathrm{~g} \mathrm{Zn} \mathrm{ha}^{-1}$ were recorded by supplementing Zn in combination with 120, 150 and $180 \mathrm{~kg} \mathrm{~N}^{-1}$, respectively. Highest uptake was recorded in SD-998 when supplied with $10 \mathrm{~kg} \mathrm{Zn}+180 \mathrm{~kg} \mathrm{~N} \mathrm{ha}^{-1}$.

Momentous and steady increase in wheat grain protein (Table 4) contents were recorded with increasing levels of $\mathrm{N}$ and maximum were recorded with $180 \mathrm{~kg} \mathrm{~N} \mathrm{ha}^{-1}$. Increasing protein contents are the direct indication to improved quality of produce. $\mathrm{Zn}$ application also influenced protein contents significantly as 10 $\mathrm{kg} \mathrm{Zn}+180 \mathrm{~kg} \mathrm{~N}^{-1}$ hawed maximum protein contents (847.75 kg ha-1) in grains of BWQ-4 followed by SD-998 (740.22 $\mathrm{kg} \mathrm{ha}^{-1}$ ) and NIA-Amber (613.25 kg ha-1).

\section{Discussion}

Increased input levels of $\mathrm{N}$ imparted higher photosynthetic activity (Rodrigues et al., 2000), cell division (Warraich et al., 2002), increased number of leaf, vigorous vegetative growth (Protic et al., 2007) and better assimilation and metabolic rates (Oscarson, 2000) which resulted in better crop productivity in wheat (Goswami, 2007). Similar responses of various levels of $\mathrm{N}$ application have been reported by Yadav et al. (2012) and Singh et al. (2013). Increase in grain and straw yield (Table 1) is due to role of Zn in stimulation and catalysis of various metabolic processes. As co-factor of enzymes $\mathrm{Zn}$ is involved in growth and development of plants eventually leading to higher yields of wheat (Imran et al., 2015). However, lower rate of $\mathrm{Zn}$ was more favorable than higher rate in terms of grain yield. Grain yield was improved with increasing rates of $\mathrm{N}$ at each level of $\mathrm{Zn}$. Combination of $5 \mathrm{~kg} \mathrm{Zn}$ and $150 \mathrm{~kg} \mathrm{~N} \mathrm{ha}^{-1}$ has more pronounced effect because these levels might have maintained optimal balance between the nutrients as artificially modified soil fertility through the addition of fertilizer in proportion to the crop needs can promote growth and increase or sustain yield. This is comparable with the results recorded by Sahay et al. (2009) and Protic et al. (2007) while studying the effect of $\mathrm{N}$ and $\mathrm{Zn}$ on wheat in deficient soils. Significant positive correlations $(\mathrm{r}=0.896)$ between mean nitrogen contents of grains and mean grain yields of tested genotypes illustrate the role of nutrients contents in better crop yield (Figure 1). The correlation $(r=0.755)$ between grain zinc contents and grain yield (Figure 2) supports the role of zinc in yield enhancement.

Table 1. Physico-chemical characteristics of the soil

\begin{tabular}{ll}
\hline Characteristics & Value \\
\hline Textural class & Silty clay loam \\
Organic matter & $0.73 \%$ \\
Electrical conductivity & $1.20 \mathrm{dS} \mathrm{m}^{-1}$ \\
$\mathrm{pH}$ & 7.56 \\
Kjeldhal nitrogen & $0.035 \%$ \\
Extractable Phosphorus & $6.8 \mu \mathrm{g} \mathrm{g}^{-1}$ \\
Extractable potassium & $145 \mu \mathrm{g} \mathrm{g}^{-1}$ \\
Extractable Zinc & $0.36 \mu \mathrm{g} \mathrm{g}^{-1}$ \\
\hline
\end{tabular}

Improved nutrient contents can be attributed to enhanced nutrient demands of plants due to escalated grain and straw yield (Brown et al., 2005). Application of $\mathrm{N}$ improved $\mathrm{Zn}$ uptake majorly due to the improved enzymes activities and more efficient metabolic processes. (Imran et al., 2015).

Phosphorus uptake (Table 3) was improved by the higher doses of $\mathrm{N}$ explains the role of $\mathrm{N}$ in enhanced $\mathrm{P}$ uptake as ammonium ions temporarily lowers the $\mathrm{pH}$ in the micro-sites of the plant roots which facilitates more P uptake in plants (Chaudhary et al., 1997; Singh et al., 2007) . This increased uptake of P in grains can also be physiological prompted rather than root system ramification. On the contrary, P uptake declined with the application of Zn might be due to antagonism between the two nutrients (Singh et al., 2010). 

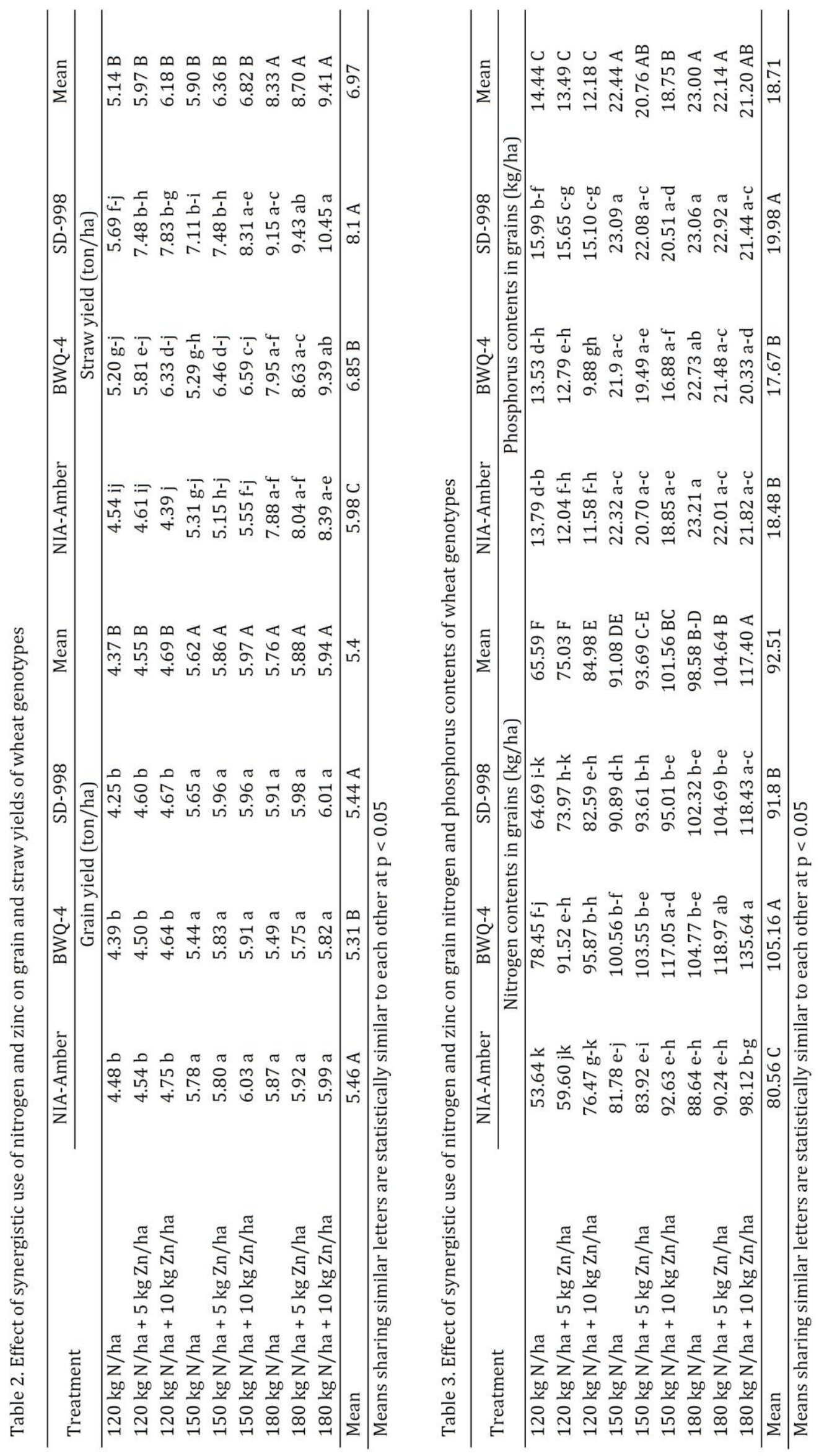


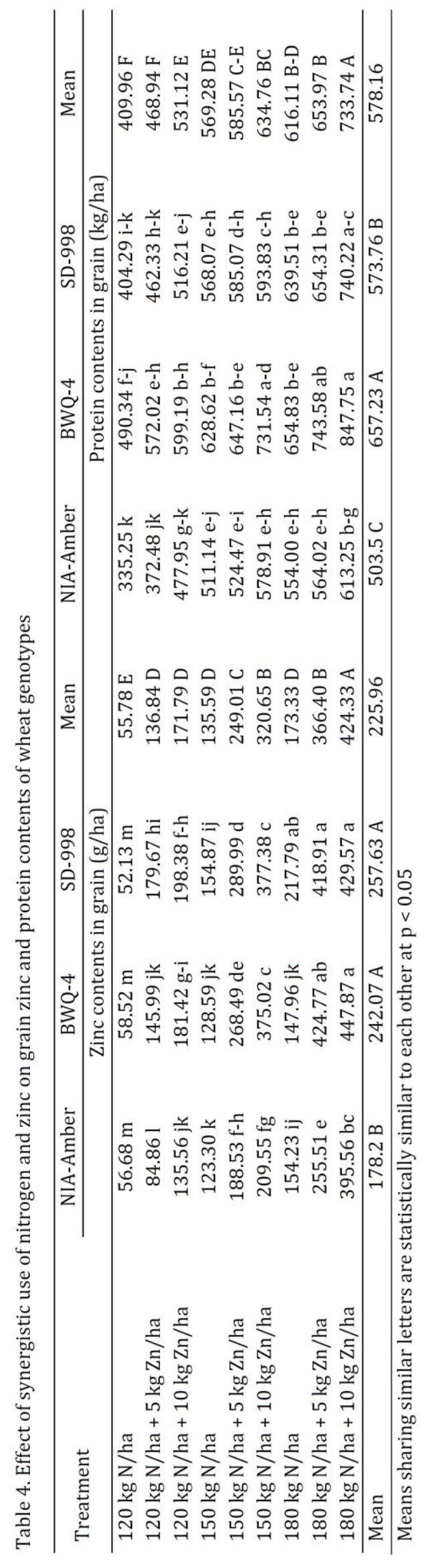


Increased $\mathrm{Zn}$ uptake in wheat grains can be attributed to the role of $\mathrm{N}$ dependent proteins in $\mathrm{Zn}$ uptake and translocation in plant (Cakmak et al., 2010b). This phenomenon can excellently be understood by taking in account of pre-anthesis accumulation of $\mathrm{Zn}$ in vegetative parts of wheat and role of $\mathrm{N}$ in extending $\mathrm{Zn}$ supply to grains during anthesis and grain filling (Kutman et al., 2012; Barunawati et al., 2013; Sperotto et al., 2013). Very strong correlation was found $(r=0.904)$ between the mean $\mathrm{N}$ contents in grains and mean $\mathrm{Zn}$ contents in grains (Figure 3), explains the positive influence of nitrogen on zinc uptake in crop.

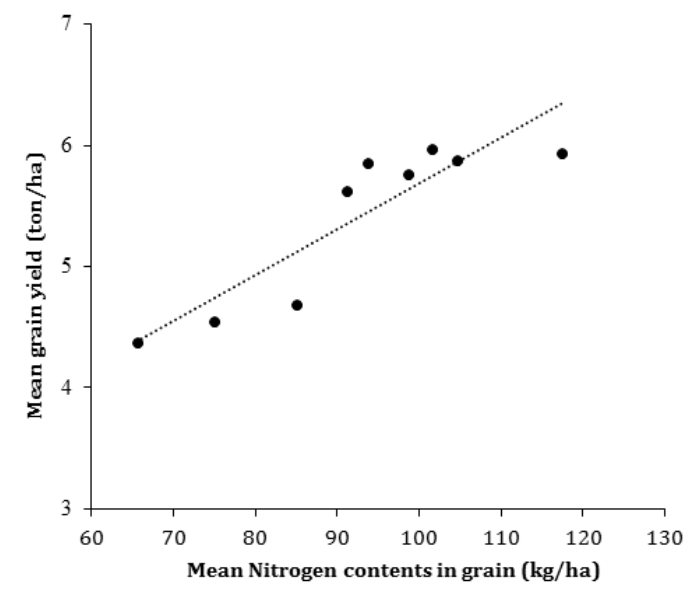

Figure 1. Correlation $(\mathrm{r}=0.896)$ between mean nitrogen contents in grains to mean grain yield of wheat genotypes

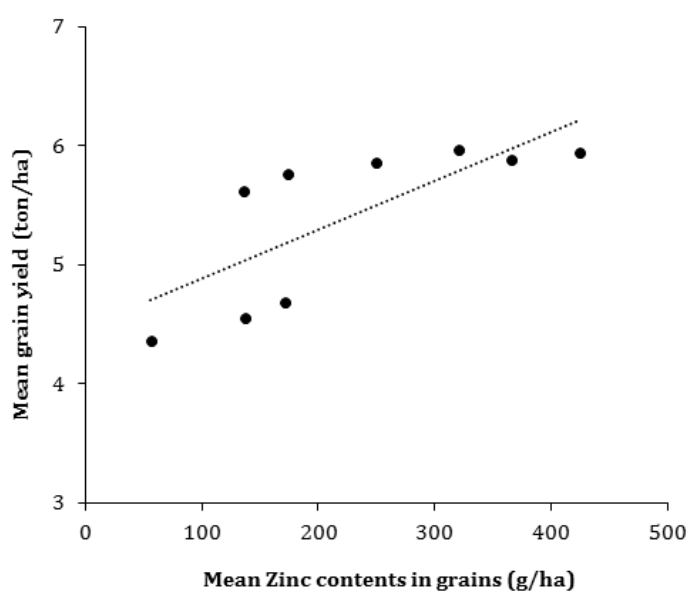

Figure 2. Correlation ( $r=0.755)$ between mean grain zinc contents to grain yield of tested wheat genotypes

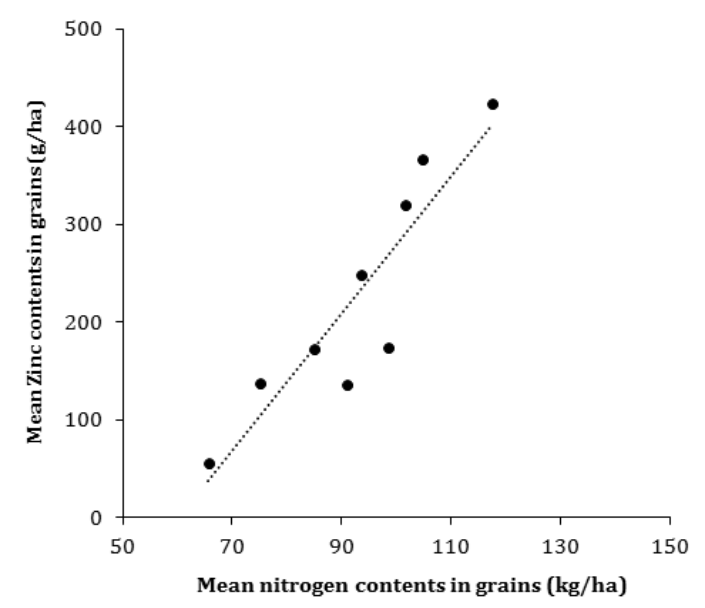

Figure 3. Correlation $(r=0.904)$ between grain nitrogen contents to grain zinc contents of tested wheat genotyptes

Plant accumulated larger concentration of $\mathrm{N}$ with the increasing $\mathrm{N}$ input levels hence depicted more grain protein contents. $\mathrm{N}$ plays pivotal role in amino acids and protein synthesis (Brown et al., 2005; Abedi et al., 2011). Therefore, its higher doses can be attributed to increased protein contents. Levels of Zn also played important role in stimulating protein contents in grains (Nadim et al., 2012; Jiang et al., 2013) Zn is indispensable nutrient for $\mathrm{N}$ metabolism due to its catalytic influence on numerous enzyme systems, biochemical activities responsible for nitrate reduction and protein synthesis (Khare and Dixit, 2011).

\section{Conclusion}

On the basis of experimental results it is concluded that $\mathrm{N}$ and $\mathrm{Zn}$ fertilization is crucial not only for the yield maximization in wheat but also to improve quality of produce. $150 \mathrm{~kg} \mathrm{~N}^{-1}$ in combination with $5 \mathrm{~kg} \mathrm{Zn} \mathrm{ha-1}^{-1}$ can be recommended as optimal dose to achieve better growth, productivity and quality of wheat.

\section{Acknowledgements}

We are grateful to Dr. Mehboob Ali Sial (Deputy Chief Scientist) and Dr. Azeem Asad (Principal Scientist) of Plant Breeding Division, Nuclear Institute of Agriculture (NIA) Tando Jam for their co-ordination in this study and provision of wheat seed. 


\section{References}

Abedi, T., Alemzadeh, A., Kazemeini, S.A., 2010. Effect of organic and inorganic fertilizers on grain yield and protein banding pattern of wheat. Australian Journal of Crop Sciences 4(6): 384-389.

Abedi, T., Alemzadeh, A., Kazemeini, S.A., 2011. Wheat yield and grain protein response to nitrogen amount and timing. Australian Journal of Crop Sciences 5(3): 330-336.

Allen, L.H., 2000. Ending hidden hunger: the history of micronutrient deficiency control. Background Analysis for the World Bank- UNICEF Nutrition Assessment Project World Bank. Washington DC, USA.

Barunawati, N., Giehl, R.F.H., Bauer B., von Wiren, N., 2013. The influence of inorganic N fertilizer forms on micronutrient retranslocation and accumulation in grains of winter wheat. Frontiers in Plant Science 4 (320): 111.

Bouis, H.E., Welch, R.M., 2010. Biofortification-A Sustainable agricultural strategy for reducing micronutrient malnutrition in the global south. Crop Science 50(S1): 20-32.

Brown, B., Westcott, M., Christensen, N., Pan, B., Starck, J., 2005. Nitrogen management for hard wheat protein enhancement. A Pacific Northwest Extension Publication, PNW 578.

Cakmak, I., 2010. Biofortification of cereals with zinc and iron through fertilization strategy. 19th World Congress of Soil Science, Soil Solutions for a Changing World, 1-6 August 2010, Brisbane, Australia. p.4-6.

Cakmak, I., Pfeiffer, W.H., McClafferty, B., 2010a. Biofortification of Durum wheat with Zn and iron. Cereal Chemistry 87 (1): 10-20.

Cakmak, I., Kalayci, M., Kaya, Y., Torun, A. A., Aydin, N., Wang, Y., Arisoy, Z., Erdem, H., Gokmen, O., Ozturk, L., Horst, W.J., 2010b. Biofortification and localization of Zn in wheat grain. Journal of Agricultural and Food Chemistry 58(16): 9092-9102.

Chapman, H.D., Pratt, P.F., 1961. Methods of analysis for soils, plants and water. University of California, Berkeley, CA, USA.

Chaudhary, N.R., Vyas, A. K., Singh, A. K., 1997. Growth and nutrient uptake in wheat as influenced by nitrogen, phosphorus and Zn application. Annals of Agricultural Research 18: 365-366.

Chauhan, T.M., Ali, J., Singh, S.P., Singh, S.B., 2014. Effect of nitrogen and zinc nutrition on yield, quality and uptake of nutrients by wheat. Annals of Plant and Soil Research 16(2): 98-101

FAO, 2013. Crop prospects and food situation. Global Information and Early Warning System on Food and Agriculture (GIEWS), Food and Agriculture Organization of the United Nations (FAO), Italy, Rome. Available at [Accessed date: 24.01.2017]: http://www.fao.org/docrep/018/aq114e/aq114e.pdf

FAO, 2003. Food energy - methods of analysis and conversion factors. FAO Food and Nutrition Paper 77. Rome, Italy. Available at [Accessed date: 24.01.2017]:

http://www.fao.org/uploads/media/FA0_2003_Food_Energy_02.pdf

Goswami, V.K., 2007. Response of wheat (Triticum aestivum) to nitrogen and zinc application. Annals of Agricultural Research New Series 28(1): 90-91.

Imran, M., Kanwal, S., Hussain, S., Aziz, T., Maqsood, M.A., 2015. Efficacy of zinc application methods for concentration and estimated bioavailability of zn in grains of rice grown on a calcareous soil. Pakistan Journal of Agricultural Sciences 52(1): 169-175

Jiang, L., Zhang, D., Song, F., Zhang, X., Shao, Y., Li, C., 2013. Effects of zinc on growth and physiological characters of flag leaf and grains of winter wheat after anthesis. Advance Journal of Food Science and Technology 5(5): 571-577.

Jones, Jr., J.B., 1991. Kjeldahl method for nitrogen determination. Micro-Macro Publishing Inc., Athens, GA, USA.

Khare, D., Dixit, H.C., 2011. Effect of potassium and zinc on yield, quality and uptake of nutrients in wheat. Annals of Plant and Soil Research 13(2): 158-160.

Kutman, U.B., Yildiz, B., Cakmak, I., 2011. Improved nitrogen status enhances zinc and iron concentrations both in the whole grain and the endosperm fraction of wheat. Journal of Cereal Science 53(1): 118-125.

Kutman, U.B., Yildiz, B., Ozturk, L., Cakmak, I., 2010. Biofortification of durum wheat with zinc through soil and foliar applications of nitrogen. Cereal Chemistry 87(1): 1-9.

Kutman. U.B., Yildiz, B.K., Ceylan, Y., Ova, E.A., Cakmak, I., 2012. Contributions of root uptake and remobilization to grain zinc accumulation in wheat depending on post-anthesis zinc availability and nitrogen nutrition. Plant and Soil 361(1): 177-187.

Marino, S., Tognetti, R., Alvino, A., 2011. Effects of varying nitrogen fertilization on crop yield and grain quality of emmer grown in a typical Mediterranean environment in central Italy. European Journal of Agronomy 34(3): 172180.

Mayer, J.E., Pfeiffer, W.H., Beyer, P., 2008. Biofortified crops to alleviate micronutrient malnutrition. Current Opinion in Plant Biology 11(2): 166-170.

Nadim, M.A., Awan, I.U., Baloch, M.S., Khan, E.A., Naveed, K., Khan, M.A., 2012. Response of wheat (Triticum aestivum L.) to different micronutrients and their application methods. Journal of Animal and Plant Sciences 22(1): 113-119.

NAMC, 2016. Climate maps. National Metrological Centre-Pakistan Metrological Department. Available at [Accessed date: 24.01.2017]: http://namc.pmd.gov.pk/climate-maps.php 
Oscarson, P., 2000. The strategy of the wheat plant in acclimating growth and grain production to nitrogen availability. Journal of Experimental Botany 51 (352): 1921 -1929.

Protic, R., Jovin, R., Protic, N., Jankovic, S., Jovanovic, Z., 2007. Mass of 1,000 grains in several winter wheat genotypes, at different dates of sowing and rates of Nitrogen fertilizer. Romanian Agricultural Research 24: 39-42.

Rashid, A., 1986. Mapping zinc fertility of soils using indicator plants and soils analyses. PhD Dissertation, University of Hawaii, HI, USA.

Riezzo, G., Chiloiro, M., Russo, F., 2005. Functional foods: salient features and clinical applications. Current Drug TargetsImmune, Endocrine and Metabolic Disorder 5(3): 331-337.

Rodrigues, O., Dinonet, D.A., Gonveia, J.A., De Cássia Soares, R., 2000. Nitrogen translocation in wheat inoculated with Azospirium. Pesquisa agropecuária Brasileria. 35(7): 1473-1481.

Ryan, J., 2000. Soil and plant analysis in the Mediterranean region: Limitations and potential. Communications in Soil Science and Plant Analysis 31(11-14): 2147 - 2154.

Sahay, N., Kumar, A., Verma, D., 2009. Effect of nitrogen and zinc on herbage yield, nutrient uptake and quality of fodder oat. Annals of Plant and Soil Research 11(2): 162-163.

Salvagiotti, F., Miralles, D.J., 2007. Wheat development as affected by nitrogen and sulfur nutrition. Australian Journal of Agricultural Research 58(1): 39-45.

Shi, R., Zhang, Y., Chen, X., Sun, Q., Zhang, F., Römheld, V., Zou, C., 2010. Influence of long-term nitrogen fertilization on micronutrient density in grain of winter wheat (Triticum aestivum L.). Journal of Cereal Science 51(1): 165 - 170.

Singh, M.V., Kumar, N., Singh, R.K., Mishra, B.N., 2010. Effect of phosphorus, sulphur and zinc on growth, yield and uptake of nutrients in late sown wheat in eastern Uttar Pradesh. Annals of Plant and Soil Research 12(2): 119121.

Singh, R.K., Singh, S.K., Singh, L.B., 2007. Integrated nitrogen management in wheat (Triticum aestivum). Indian Journal of Agronomy 52(2): 124-126

Singh, V., Singh, S.P., Singh, S., Shivay, Y.S., 2013. Growth, yield and nutrient uptake by wheat (Triticum aestivum) as affected by biofertilizers, FYM and nitrogen. Indian Journal of Agricultural Sciences 83(3): 331-334.

Sperotto, R.A., Ricachenevsky, F.K., Waldow, V., de A., Müller, A.L.H., Dressler, V.L., Fett, J.P., 2013. Rice grain Fe, Mn and Zn accumulation: How important are flag leaves and seed number? Plant Soil and Environment 59(6): 262-266.

Stein, A.J., 2006. Micronutrient malnutrition and the impact of modern plant breeding on public health in India: How Cost-effective is Biofortification? Cuvillier Verlag, Göttingen, Germany. 162p.

Stein, A.J., Nestel, P., Meenakshi, J.V., Qaim, M., Sachdev H.P., Bhutta, Z.A., 2007. Plant breeding to control zinc deficiency in India: how cost-effective is biofortification? Public Health and Nutrition 10(5): 492-501.

Takahashi, M., Terada, Y., Nakai, I., Nakanishi, H., Yoshimura, E., Mori, S., Nishizawa, N.K., 2003. Role of nicotianamine in the intracellular delivery of metals and plant reproductive development. The Plant Cell 15(6): 1263-1280.

UNO, 2004. United Nations Standing Committee on Nutrition: Fifth Report on the World Nutrition Situation - Nutrition for Improved Development Outcomes.

Vijayaraghavan, K., 2002. Control of micronutrient deficiencies in India: obstacles and strategies. Nutrition Reviews 60(S5): 73-76.

Vincent, J.E., Menefee, A.M., 2007. Vitamin A supplementation including older children: A refugee population on the Thailand-Burma border. Sight and Life Magazine 2/2007: 16-19.

Wang, Y. X., Specht, A., Horst, W.J., 2011. Stable isotope labelling and zinc distribution in grains studied by laser ablation ICP-MS in an ear culture system reveals zinc transport barriers during grain filling in wheat. New Phytologist 189(2): 428-437.

Warraich, E.A., Ahmed, N., Basra, S.M.A., Afzal, I., 2002. Effect of nitrogen on source-sink relationship in wheat. International Journal of Agriculture and Biology 4(2): 300-302.

Welch, R.M., Graham, R.D., 2004. Breeding for micronutrients in staple food crops from a human nutrition perspective. Journal of Experimental Botany 55(96): 353-364.

Yadav, A.K., Chauhan, S.K., Shroti, S.K., 2012. Effect of sowing dates and nitrogen levels on yield and economics of vegetable pea-wheat-maize cropping system in central part of Uttar Pradesh. Annals of Plant and Soil Research 14(2): 159-162. 